\title{
A new method to discriminate secondary organic aerosols from different sources using high-resolution aerosol mass spectra
}

\author{
M. F. Heringa ${ }^{1}$, P. F. DeCarlo ${ }^{1, *}$, R. Chirico ${ }^{1,{ }^{* *}}$, T. Tritscher ${ }^{1, * * *}$, M. Clairotte ${ }^{2}$, C. Mohr $^{1,{ }^{* * * *}}$, M. Crippa $^{1}$, \\ J. G. Slowik ${ }^{1}$, L. Pfaffenberger ${ }^{1}$, J. Dommen ${ }^{1}$, E. Weingartner ${ }^{1}$, A. S. H. Prévôt ${ }^{1}$, and U. Baltensperger ${ }^{1}$ \\ ${ }^{1}$ Laboratory of Atmospheric Chemistry, Paul Scherrer Institut, 5232 Villigen PSI, Switzerland \\ ${ }^{2}$ European Commission Joint Research Centre Ispra, Institute for Energy and Transport, Sustainable Transport Unit, \\ 21027 Ispra (VA), Italy \\ * now at: Department of Civil, Architectural and Environmental Engineering, Drexel University, Philadelphia, USA \\ *** now at: Italian National Agency for New Technologies, Energy and Sustainable Economic Development (ENEA), \\ UTAPRAD-DIM, Via E. Fermi 45, 00044 Frascati, Italy \\ *** now at: TSI GmbH, Particle Instruments, Neuköllner Str. 4, 52068 Aachen, Germany \\ ***** now at: Department of Atmospheric Sciences, University of Washington, Seattle, USA
}

Correspondence to: A. S. H. Prévôt (andre.prevot@psi.ch)

Received: 12 October 2011 - Published in Atmos. Chem. Phys. Discuss.: 27 October 2011

Revised: 9 February 2012 - Accepted: 16 February 2012 - Published: 28 February 2012

\begin{abstract}
Organic aerosol (OA) represents a significant and often major fraction of the non-refractory $\mathrm{PM}_{1}$ (particulate matter with an aerodynamic diameter $d_{\mathrm{a}}<1 \mu \mathrm{m}$ ) mass. Secondary organic aerosol (SOA) is an important contributor to the OA and can be formed from biogenic and anthropogenic precursors. Here we present results from the characterization of SOA produced from the emissions of three different anthropogenic sources. SOA from a log wood burner, a Euro 2 diesel car and a two-stroke Euro 2 scooter were characterized with an Aerodyne high-resolution time-of-flight aerosol mass spectrometer (HR-TOF-AMS) and compared to SOA from $\alpha$-pinene.
\end{abstract}

The emissions were sampled from the chimney/tailpipe by a heated inlet system and filtered before injection into a smog chamber. The gas phase emissions were irradiated by xenon arc lamps to initiate photo-chemistry which led to nucleation and subsequent particle growth by SOA production.

Duplicate experiments were performed for each SOA type, with the averaged organic mass spectra showing Pearson's $r$ values $>0.94$ for the correlations between the four different SOA types after five hours of aging. High-resolution mass spectra (HR-MS) showed that the dominant peaks in the MS, $m / z 43$ and 44 , are dominated by the oxygenated ions $\mathrm{C}_{2} \mathrm{H}_{3} \mathrm{O}^{+}$and $\mathrm{CO}_{2}^{+}$, respectively, similarly to the relatively fresh semi-volatile oxygenated OA (SV-OOA) observed in the ambient aerosol. The atomic $\mathrm{O}: \mathrm{C}$ ratios were found to be in the range of $0.25-0.55$ with no major increase during the first five hours of aging. On average, the diesel SOA showed the lowest O:C ratio followed by SOA from wood burning, $\alpha$-pinene and the scooter emissions. Grouping the fragment ions revealed that the SOA source with the highest O:C ratio had the largest fraction of small ions.

The HR data of the four sources could be clustered and separated using principal component analysis (PCA). The model showed a significant separation of the four SOA types and clustering of the duplicate experiments on the first two principal components (PCs), which explained $79 \%$ of the total variance. Projection of ambient SV-OOA spectra resolved by positive matrix factorization (PMF) showed that this approach could be useful to identify large contributions of the tested SOA sources to SV-OOA. The first results from this study indicate that the SV-OOA in Barcelona is strongly influenced by diesel emissions in winter while in summer at SIRTA at the southwestern edge of Paris SV-OOA is more similar to alpha-pinene SOA. However, contributions to the ambient SV-OOA from SOA sources that are not covered by the model can cause major interference and therefore future expansions of the PCA model with additional SOA sources is recommended. 


\section{Introduction}

Particulate matter (PM) in the air consists of a complex mixture of organic matter $(\mathrm{OM})$, elemental carbon (EC), inorganic salts as well as trace elements and mineral dust. Primary aerosol particles are directly emitted as particles from sources like biomass burning and the use of fossil fuels as well as volcanic eruptions or the suspension of soil and dust. Secondary aerosols, however, are formed by the reaction of gas phase precursors from biogenic or anthropogenic origin, which leads to a decrease in volatility resulting in a shift in partitioning from the gas phase to the particle phase with increased PM levels as result (Donahue et al., 2006). Atmospheric aerosols contribute to various adverse effects on human health (Nel, 2005; Pope and Dockery, 2006) and have an important impact on visibility (Watson, 2002) and climate (IPCC, 2007).

Organic aerosol (OA) represents a substantial and often major fraction of the non-refractory $\mathrm{PM}_{1}$ (PM with an aerodynamic diameter $d_{\mathrm{a}}<1 \mu \mathrm{m}$ ) mass in many parts of the world (Jimenez et al., 2009; Zhang et al., 2007). Primary OA (POA), as well as secondary OA (SOA) produced by the oxidation of volatile organic compounds (VOC) in the atmosphere, contributes to the total OA concentration where SOA generally comprises the major fraction of atmospheric OA (Robinson et al., 2007).

Biogenic emissions, like isoprene and terpenes, are an important source of VOCs in the atmosphere and constitute a major SOA source. However, it has recently been shown that the gas phase emissions from major POA sources such as wood combustion (Grieshop et al., 2009; Heringa et al., 2011), diesel cars without emission abatement devices (Chirico et al., 2010) and scooters (Platt et al., 2012) can produce SOA concentrations that exceed the initial POA emissions. The global SOA formation from volatile organic precursors is estimated at $115 \mathrm{Tg} \mathrm{Cyr}^{-1}$ which comprises approximately $70 \%$ of the organic carbon (OC) PM mass of which $23 \%$ is from biomass burning and anthropogenic activities (Hallquist et al., 2009). However, depending on the emission profile on a regional scale, the importance of the various sources of SOA can be substantially different.

Quantification of the contributions of different ambient OA sources was performed by the deconvolution of the OA mass spectra from the Aerodyne aerosol mass spectrometer (AMS) by positive matrix factorization (PMF) (Lanz et al., 2007). POA sources such as hydrocarbon-like OA (HOA) from traffic and biomass burning OA (BBOA) were distinguished in many datasets (Lanz et al., 2010; Jimenez et al., 2009). More recently, cooking was identified as a major POA source (Allan et al., 2010; Sun et al., 2011; Crippa et al., 2012; Huang et al., 2010; Mohr et al., 2012). However, SOA is typically represented only as a linear combination of low volatility and semi-volatile oxygenated organic aerosol factors (LV-OOA and SV-OOA, respectively). LVOOA is considered more aged and exhibits a higher O:C ratio, while SV-OOA represents fresher OOA with a lower O:C ratio (DeCarlo et al., 2010; Lanz et al., 2007; Ng et al., 2010); however, these factors typically provide limited information regarding the identity of their source emissions. Smog chamber and field studies showed that the correlation between the AMS spectra of different OA sources and ambient LV-OOA increases with aging, implying that the original fingerprint is lost and the various SOA types converge to produce a general, highly oxidized LV-OOA signature, reducing the utility of fingerprint-based apportionment techniques such as chemical mass balance (Capes et al., 2008; Jimenez et al., 2009). In addition, it is likely that the diurnal variation of the SOA from different sources is driven by the level of oxidizing species in the atmosphere, reducing the temporal differences necessary for their deconvolution by receptor modeling techniques (e.g. PMF). Although other techniques, like organic tracers, PMF and modeling can supply information about different POA and SOA sources (Kleindienst et al., 2007; Lewandowski et al., 2008; Schwartz et al., 2010; Farina et al., 2010; Andreani-Aksoyoglu et al., 2008), the high time resolution of the AMS in combination with the ability to measure quantitatively the major fraction of $\mathrm{PM}_{1} \mathrm{OA}$, AMS data could supply important information for the quantification of SOA from different sources.

In this paper, we describe the properties of fresh and aged SOA from the gas phase emissions of a log wood burner, a Euro 2 diesel car without emission abatement devices and a Euro 2 scooter. Mass spectral features of SOA are depending on many parameters like $\mathrm{VOC} / \mathrm{NO}_{\mathrm{x}}$ ratio, concentration and temperature. Therefore, the models shown in this manuscript, based on the results of laboratory studies on real emission sources, are not necessarily identical to the results that can be expected during all ambient conditions. Additionally, variability in emissions from sources like wood burning adds to the uncertainty described above. The mass spectral features of these anthropogenic sources were measured with a high-resolution time-of-flight aerosol mass spectrometer (HR-TOF-AMS) and compared to the spectra from SOA produced by the ozonolysis and photo-oxidation of $\alpha$-pinene. Principal component analysis (PCA) was applied on all ions to separate the different SOA spectra. A new method is presented to group the ions of the organic mass spectrum based on the number of carbon and oxygen atoms of the fragments which helps to facilitate the comparison of different spectra and to present a simplified method to separate the different SOA sources presented in this paper.

\section{Materials and methods}

\subsection{Experimental setup}

The SOA experiments were performed in the smog chamber of the Paul Scherrer Institute (PSI). The PSI chamber is a $27-\mathrm{m}^{3}$ Teflon bag suspended in a temperature-controlled 


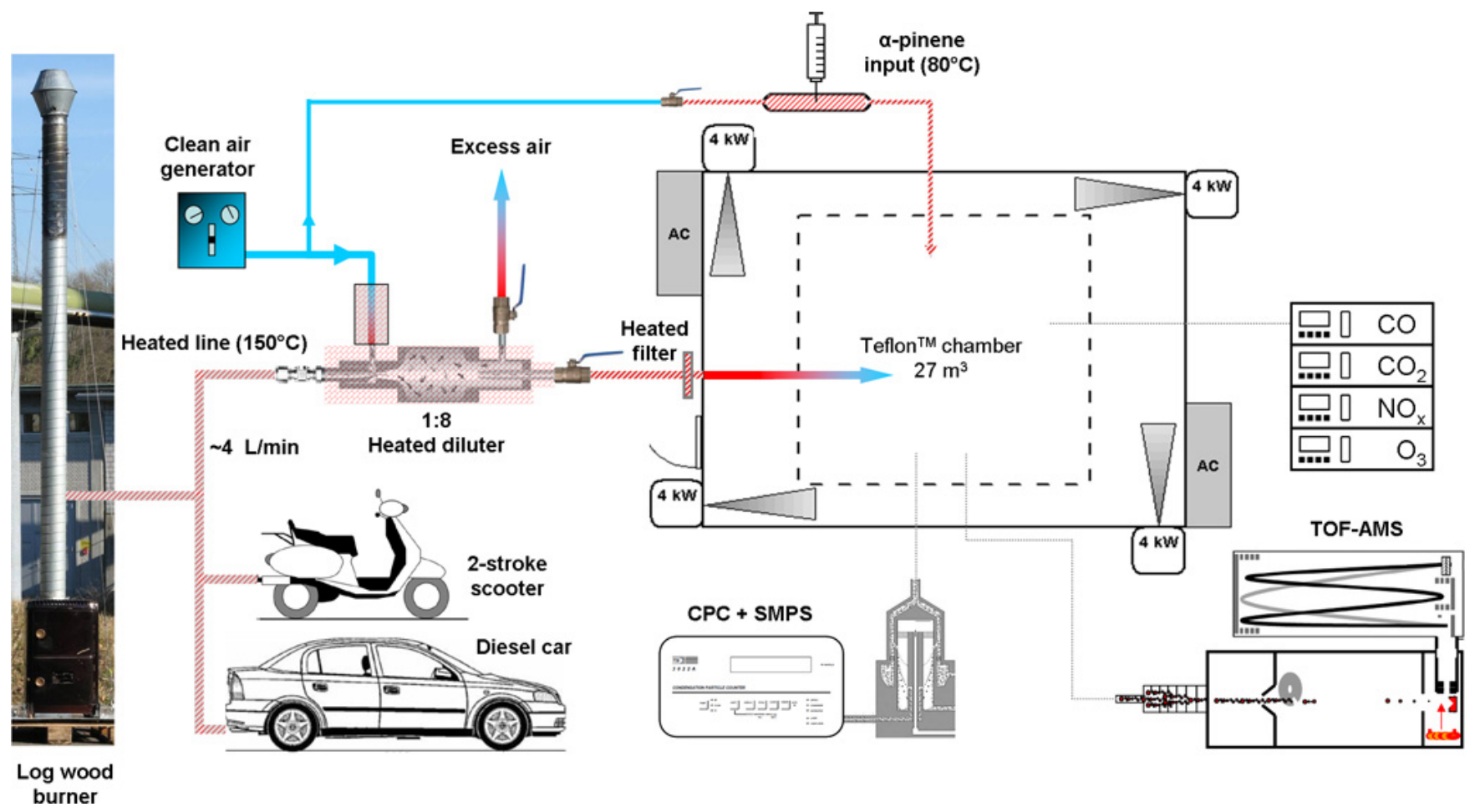

Fig. 1. Schematic representation of the inlet system and smog chamber setup.

housing. The smog chamber was operated at $20^{\circ} \mathrm{C}$ and a relative humidity $(\mathrm{RH})$ of $\sim 50 \%$ during all experiments described here. Four xenon arc lamps of $4 \mathrm{~kW}$ each were used to simulate the solar light spectrum and intensity during a typical Swiss winter day at noon. During one experiment, the UV light intensity was increased by 80 black lights (Philips, Cleo performance $100 \mathrm{~W} / \mathrm{R}$ ) positioned at the floor of the smog chamber housing to accelerate the aging process. The interior of the smog chamber housing is covered with a reflecting coating to increase light intensity and light diffusion. A more detailed description of the PSI smog chamber and its standard instrumentation can be found elsewhere (Paulsen et al., 2005).

The experiments were performed on the gas phase emissions of a modern residential log wood burner (Attika Avant, 2009), a Euro 2 diesel car without emission abatement devices (Volkswagen Transporter TDI Syncro, 2000) and a Euro 2 scooter (Piaggio Liberty 50 2-stroke, 2010). More information about the wood burner, the diesel car and the scooter as well as details of the specific smog chamber setup can be found in Heringa et al. (2011), Chirico et al. (2010) and Platt et al. (2012), respectively.

The introduction of the emissions into the chamber was done from a sampling point in the middle of the chimney or at the back of the tailpipe. Emissions were diluted in the inlet system by a factor of $\sim 7$ using a heated ejector diluter (Dekati Ltd., Tampere, Finland) using preheated dilution air provided by a pure air generator (737-250 series, AADCO
Instruments, Inc., USA). The diluted emissions were filtered through a heated filter (borosilicate glass microfiber filter, HC free and H131R, Headline filters) right before the injection point at the smog chamber. The dilution system, dilution air, filter system and all sampling lines were operated at $150^{\circ} \mathrm{C}$ to prevent condensation of semi-volatile organic compounds (SVOCs) in the inlet system. Finally, the gas phase emissions experienced a second dilution and cooling to $20^{\circ} \mathrm{C}$ when entering the smog chamber.

The $\alpha$-pinene experiments were performed by injecting $7.2-9.0 \mu \mathrm{l} \alpha$-pinene $(98 \%$, Aldrich) in a preheated tube $\left(80^{\circ} \mathrm{C}\right)$ which is continuously flushed by pure air into the smog chamber for $\sim 15 \mathrm{~min}$ after injection. A schematic representation of the inlet system and the smog chamber setup is shown in Fig. 1.

The $\alpha$-pinene ozonolysis experiment was performed by injecting the $\alpha$-pinene into the smog chamber containing $500 \mathrm{ppb}$ of ozone. For all the photo-oxidation experiments, after injection of the combustion emissions or $\alpha$-pinene, a 15min homogenization period was taken into account before the starting conditions were analyzed and the xenon lamps were switched on to start photo-oxidation. For each source, wood burning, diesel, scooter and $\alpha$-pinene, a five-hour and a ten-hour experiment was conducted. An overview of the experiments described in this paper can be found in Table 1 .

After each experiment the smog chamber was cleaned by the addition of several ppm of ozone for $\sim 3-4 \mathrm{~h}$ and flushing the chamber with zero air for at least $36 \mathrm{~h}$. Blank experiments 
Table 1. Overview of the experimental parameters for the different smog chamber experiments.

\begin{tabular}{|c|c|c|c|c|c|}
\hline Experiment & $\begin{array}{l}\text { Experiment } \\
\text { type }\end{array}$ & $\begin{array}{l}\text { Duration } \\
\text { (h) }\end{array}$ & $\begin{array}{c}\mathrm{SOA}_{5 \mathrm{~h}} \\
\left(\mu \mathrm{g} \mathrm{m}^{-3}\right)\end{array}$ & $\begin{array}{c}\mathrm{SOA}_{5 \mathrm{~h}} \\
\mathrm{O}: \mathrm{C}\end{array}$ & $\begin{array}{c}\mathrm{NO}_{\mathrm{x}(t 0)} \\
(\mathrm{ppb})\end{array}$ \\
\hline \multicolumn{6}{|l|}{ Log wood burner ${ }^{\mathrm{a}}$} \\
\hline 1 Start and flaming phase & Xenon & 5 & 5.3 & 0.36 & 27 \\
\hline 2 Start and flaming phase & Xenon & 10 & 14.2 & 0.39 & 44 \\
\hline \multicolumn{6}{|l|}{ Diesel car (Euro 2) ${ }^{\mathrm{b}}$} \\
\hline 1 Cold start idle & Xenon & 10 & 4.1 & 0.39 & 153 \\
\hline 2 Cold start idle & Xenon & 5 & 8.4 & 0.29 & 142 \\
\hline \multicolumn{6}{|l|}{ Scooter (Euro 2) } \\
\hline 1 Low engine load & Xenon/BL ${ }^{c}$ & 10 & 15.1 & 0.48 & 29 \\
\hline 2 Low engine load & Xenon/BL ${ }^{\mathrm{d}}$ & 5 & 74 & 0.54 & 31 \\
\hline \multicolumn{6}{|l|}{$\alpha$-pinene } \\
\hline $140 \mathrm{ppb} \alpha$-pinene & $500 \mathrm{ppb} \mathrm{O}_{3}$ & 10 & 41 & 0.36 & $<1$ \\
\hline $263 \mathrm{ppb} \alpha$-pinene & Xenon & 5 & 20 & 0.42 & 270 \\
\hline
\end{tabular}

a Wood burning experiments 1 and 2 correspond to experiments 18 and 19, respectively in Heringa et al. (2011).

b Diesel experiments 1 and 2 correspond to experiments 18 and 19, respectively in Chirico et al. (2010).

c Start with 4 xenon arc lamps. After 5 h 80 black lights (BL) were added.

d Start with 4 xenon arc lamps and 40 black lights (BL). After 3.75 h 40 additional black lights were added.

with no aerosol input were performed to make sure that the OM produced during the experiments was not significantly influenced by impurities in the smog chamber.

\subsection{Instrumentation}

\subsubsection{High-resolution time-of-flight aerosol mass spectrometer}

An Aerodyne high-resolution time-of-flight aerosol mass spectrometer (HR-TOF-AMS) was used for the on-line quantification of the submicron non-refractory aerosol components. The term "non-refractory" is assigned to those species that evaporate rapidly at $600^{\circ} \mathrm{C}$ and $\sim 10^{-7}$ torr, e.g. OA, $\mathrm{NH}_{4} \mathrm{NO}_{3}$ and $\left(\mathrm{NH}_{4}\right)_{2} \mathrm{SO}_{4}$ (Allan et al., 2004). A detailed description of the HR-TOF-AMS is given in DeCarlo et al. (2006).

The high mass resolution and accuracy of the HR-TOFAMS made it possible to determine the elemental composition of the ions up to approximately $\mathrm{m} / z .100$ (DeCarlo et al., 2006). Integration of the organic ions with the elemental composition $\mathrm{C}_{\mathrm{x}} \mathrm{H}_{\mathrm{y}} \mathrm{O}_{\mathrm{z}} \mathrm{N}_{\mathrm{p}}^{+}$gives information on the elemental ratios of O:C, H:C, N:C as well as the OM:OC ratio (Aiken et al., 2007, 2008). Based on their elemental composition, ions were grouped into four different families: $\mathrm{C}_{\mathrm{x}} \mathrm{H}_{\mathrm{y}}(x \geq 1$ and $y \geq 0), \mathrm{C}_{\mathrm{x}} \mathrm{H}_{\mathrm{y}} \mathrm{O}_{\mathrm{z}}, \mathrm{C}_{\mathrm{x}} \mathrm{H}_{\mathrm{y}} \mathrm{N}_{\mathrm{p}}$ and $\mathrm{C}_{\mathrm{x}} \mathrm{H}_{\mathrm{y}} \mathrm{O}_{\mathrm{z}} \mathrm{N}_{\mathrm{p}}(x \geq 1, y \geq 0$, $z \geq 1$ and $p \geq 1$ ). These families will be referred to as $\mathrm{CH}$, $\mathrm{CHO}, \mathrm{CHN}$ and $\mathrm{CHON}$ from hereon.

Besides the family groups, a new method was used to group the ions of the organic mass spectrum based on the number of carbon and oxygen atoms of the fragments. Per carbon atom number $x$, the following three groups were de- fined: $\mathrm{C}_{\mathrm{x}}, \mathrm{C}_{\mathrm{x}} \mathrm{O}_{1}$ and $\mathrm{C}_{\mathrm{x}} \mathrm{O}_{>1}$. Grouping the ions with a number of carbon atoms up to 7 , the 21 groups covered $>95 \%$ of the signal of the organic mass spectrum in the $\mathrm{m} / \mathrm{z}$ range $12-120$.

Data analysis was performed using Igor Pro 6 (Wavemetrics, Lake Oswego, OR) with the Squirrel TOF analysis toolkit v1.48 and the TOF HR analysis toolkit v1.07. During every experiment, after filling and before lights on, HEPA filtered air was sampled from the smog chamber to measure the gas phase contributions to the mass spectra. The AMS fragmentation table (Allan et al., 2004) was modified accordingly for $m / z, 16,18,29$ and 44. In addition, the improved fragmentation table (Aiken et al., 2008) was used with the following fragmentation patterns in relation to the measured $\mathrm{CO}_{2}^{+}$signal: $\mathrm{CO}^{+}=100 \%, \mathrm{H}_{2} \mathrm{O}^{+}=22.5 \%, \mathrm{OH}^{+}=5.625 \%(25 \%$ of $\left.\mathrm{H}_{2} \mathrm{O}^{+}\right), \mathrm{O}^{+}=0.90 \%\left(4 \%\right.$ of $\mathrm{H}_{2} \mathrm{O}^{+}$). The contributions of these ions were added to the $\mathrm{CHO}$ family. A particle collection efficiency (CE) of 1 was used to estimate the nonrefractory aerosol mass concentration.

PCA was applied to the AMS spectra in order to classify the different types of SOA produced in the smog chamber. Statistical calculations were carried out in the R-statistical environment (GNU project) with the "ade4" package (Dray and Dufour, 2007).

\subsubsection{Additional instrumentation}

The evolution of several gas phase species was measured during the experiments. Carbon dioxide $\left(\mathrm{CO}_{2}\right)$ was measured using a differential, non-dispersive, infrared (NDIR) gas analyzer (LI-7000, LI-COR Biosciences) operated with 

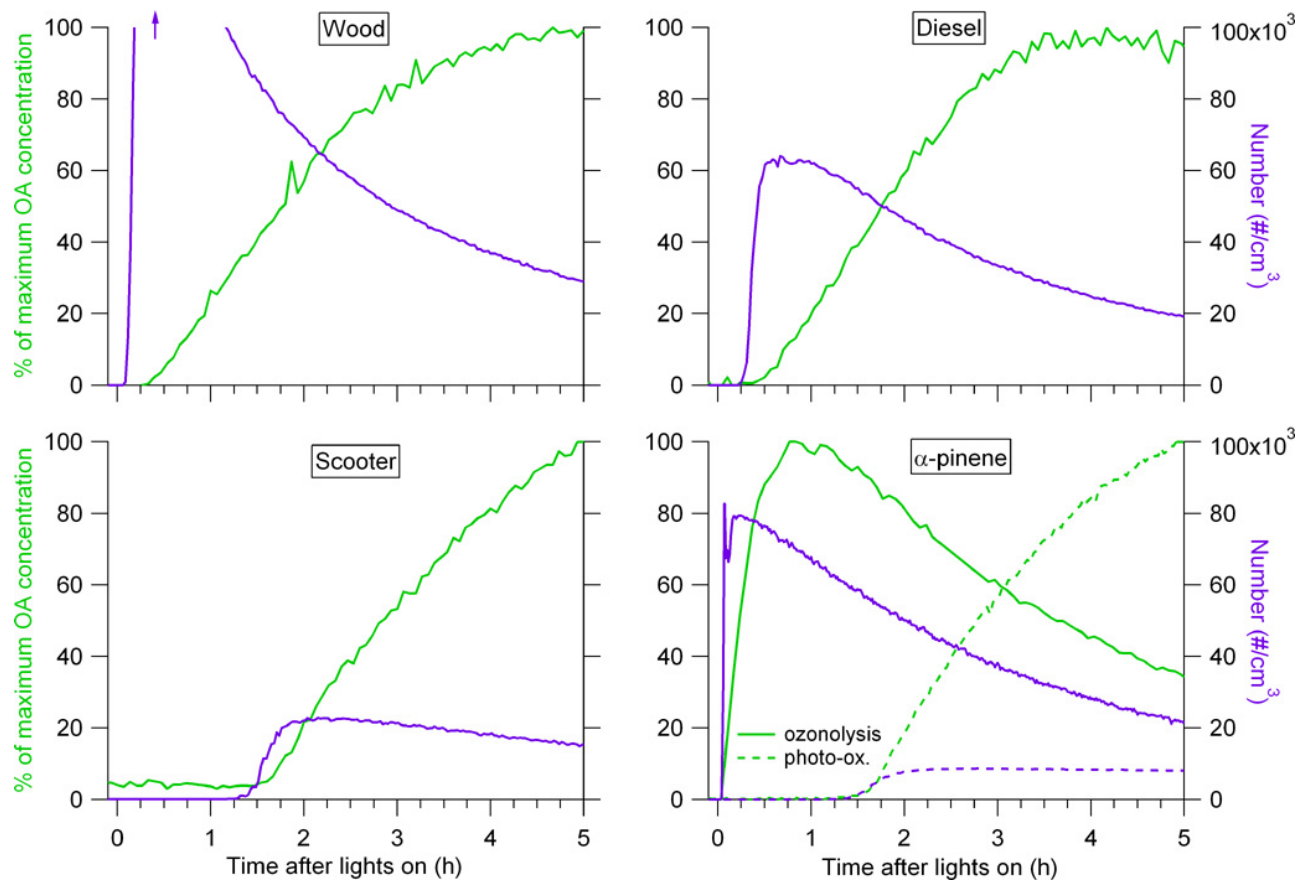

Fig. 2. Temporal evolution of the organic species normalized to the maximum concentration observed during five hours of aging and the number concentration. The time axis for the ozonolysis $\alpha$-pinene experiment represents the time after the $\alpha$-pinene addition to the chamber containing $500 \mathrm{ppb}$ ozone.

a time resolution of one second. Carbon monoxide (CO) was measured with an ultra fast fluorescence analyzer (AL5002, Aero-laser $\mathrm{GmbH})$. A chemiluminescence $\mathrm{NO}_{\mathrm{x}}$ analyzer (Monitor Labs model ML9841A) was used to measure NO and $\mathrm{NO}_{\mathrm{x}}\left(\mathrm{NO}+\mathrm{NO}_{2}\right)$ and ozone $\left(\mathrm{O}_{3}\right)$ was measured with an ozone analyzer (Monitor Labs Inc. Model 8810). Total particle number concentrations were measured with an ultrafine condensation particle counter (CPC, model 3025A, TSI) with a detection limit (50\% efficiency) of 3-nm particles.

\section{Results and discussion}

\subsection{Secondary organic aerosol production}

Figure 2 shows the evolution of the OM and total particle number concentration for the wood burning, diesel and scooter experiments as well as the $\alpha$-pinene ozonolysis and $\alpha$-pinene photo-oxidation experiments. The wood burning experiments showed almost instantaneous particle formation after the lights were switched on indicating that possibly one single oxidation reaction of precursors is enough to lower their saturation vapor pressure enough to trigger nucleation. Similar behavior was observed for the diesel experiments. The photo-oxidation of the scooter emissions and the $\alpha$ pinene showed nucleation after $\sim 1.5 \mathrm{~h}$. The latter experiments did not reach their maximum concentration of $\mathrm{OM}$ within the first five hours after the lights were switched on, in contrast to the former (Fig. 2).

Wall losses, as the result of the finite size of the smog chamber, lead to a decrease in the OM concentration when the production rate becomes slower than the wall loss rate. This phenomenon is clearly seen during the $\alpha$-pinene ozonolysis experiment where the maximum OM concentration occurs after one hour, followed by a slow decrease. The focus of this paper is on the chemical properties of the SOA from the different sources and therefore no wall loss correction routines were needed. Quantification of the SOA formation and the emission factors of the wood burner, diesel car and scooter can be found in Heringa et al. (2011), Chirico et al. (2010) and Platt et al. (2012), respectively.

\subsection{High resolution AMS data interpretation}

Photochemical aging experiments on wood smoke and diesel exhaust showed that the unit mass resolution (UMR) AMS spectra become progressively more similar to SV-OOA and LV-OOA by the formation of SOA. Jimenez et al. (2009) demonstrated that the correlation between the spectra of these two sources and an ambient SV-OOA spectrum showed an increase in correlation $\left(r^{2}\right)$ from $\sim 0.6$ to $\sim 0.9$ for wood smoke and $\sim 0.4$ to $\sim 0.8$ for diesel exhaust after only three hours of aging.

The high resolution organic mass spectra (HR-MS) were fitted with a fitting procedure resulting in a peak separation 

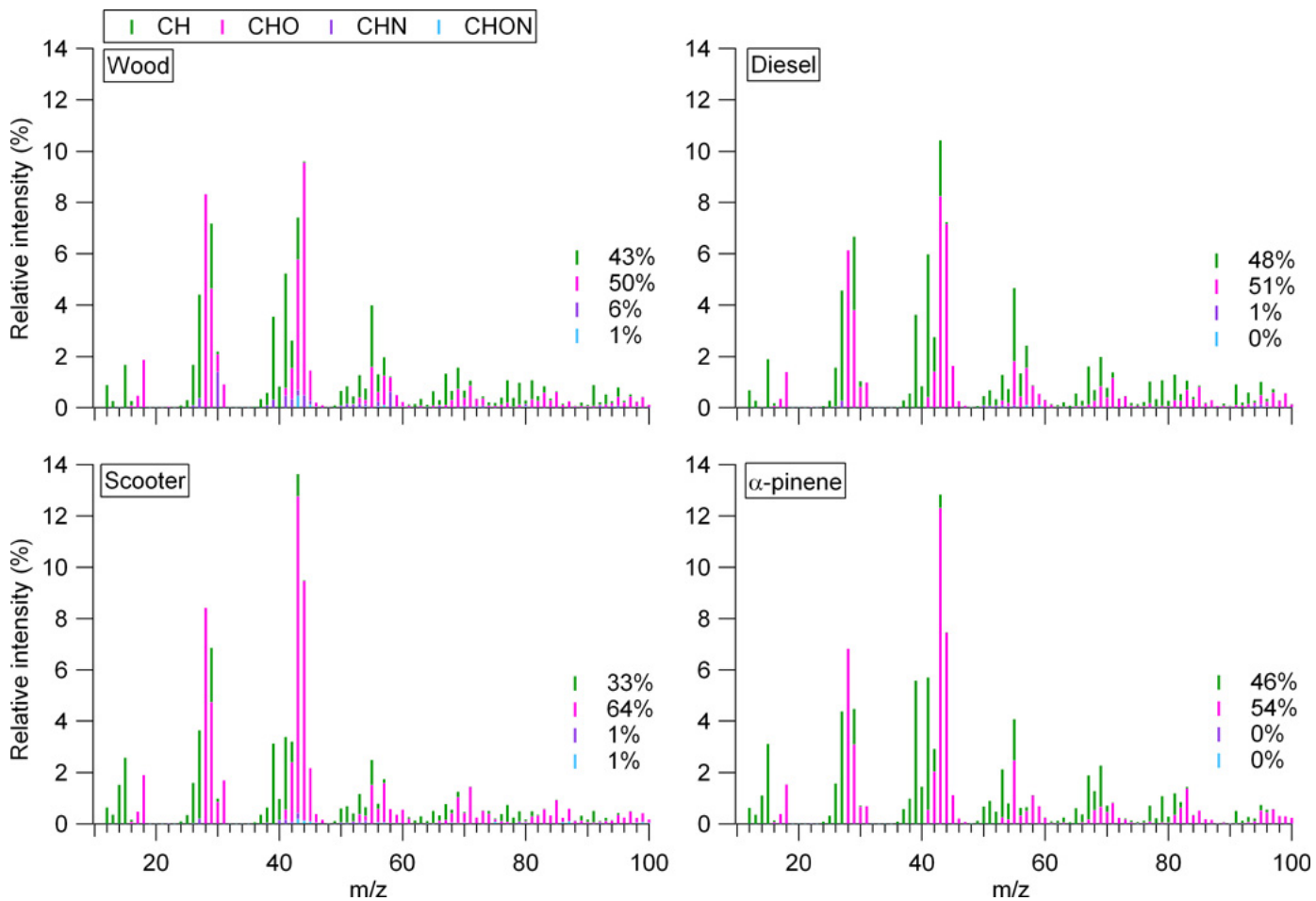

Fig. 3. Comparison of the normalized high-resolution family mass spectra after five hours of aging. Ions are grouped into the families $\mathrm{CH}$, $\mathrm{CHO}, \mathrm{CHN}$ and $\mathrm{CHON}$ based on their elemental composition. The spectra shown for wood, diesel and scooter are averages of the two experiments. The $\alpha$-pinene spectrum is from the ozonolysis experiment.

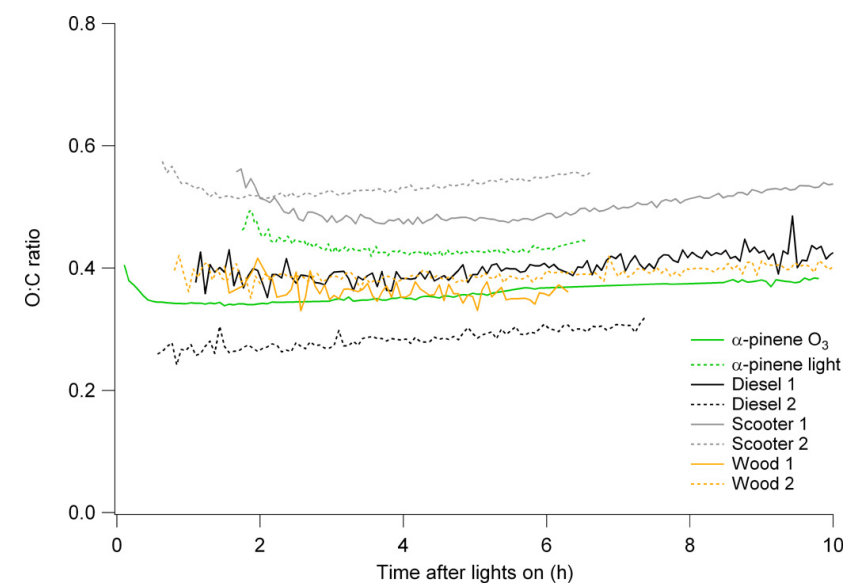

Fig. 4. O:C ratio vs. experimental time for the different sources. The time axis for the $\alpha$-pinene ozonolysis experiment represents the time after the $\alpha$-pinene addition to the chamber containing $500 \mathrm{ppb}$ ozone.

by fragment ions in the $m / z$ range 12-120 (DeCarlo et al., 2006). These fitted ions were grouped according to their molecular composition into the $\mathrm{CH}, \mathrm{CHO}, \mathrm{CHN}$ and $\mathrm{CHON}$ families. The $\mathrm{CHN}$ and $\mathrm{CHON}$ families have a minor contribution to the SOA spectra after five hours of aging. The sum of the $\mathrm{CHN}$ and $\mathrm{CHON}$ was found to be $<7 \%$ for all spectra shown in Fig. 3. The CHO family dominated all four spectra with contributions of $50 \%, 51 \%, 64 \%$ and $54 \%$ for wood burning, diesel, scooter and $\alpha$-pinene ozonolysis spectra, respectively. Remarkably, the scooter SOA showed the highest fraction of oxidized hydrocarbons with the $\mathrm{C}_{2} \mathrm{H}_{3} \mathrm{O}^{+}$ion at $\mathrm{m} / z 43.0184$ being the largest peak at $12.4 \%$ of the HR-MS. The peak at $\mathrm{m} / \mathrm{z}, 43$ is also a dominant peak in the diesel car and scooter POA, however, in the POA spectrum it is dominated by the $\mathrm{C}_{3} \mathrm{H}_{7}^{+}$fragment. All four HR spectra showed that the major peaks at $\mathrm{m} / z, 43$ and 44 are dominated by the oxygenated ions $\mathrm{C}_{2} \mathrm{H}_{3} \mathrm{O}^{+}$and $\mathrm{CO}_{2}^{+}$, respectively, also observed for SV-OOA in the ambient aerosol (Ng et al., 2010).

Based on the high resolution AMS data the elemental composition and the atomic ratios of the bulk $\mathrm{OM}$ can be calculated (Aiken et al., 2007). The O:C ratio of the OM, an approximation for the degree of oxidation, can be used to estimate the hygroscopicity and generally increases with aging time. This bulk organic property can change by condensation of SOA, accretion reactions and heterogeneous chemistry. In addition, molecules in equilibrium between the particle phase and the gas phase can evaporate, oxidize in the gas phase and condense again as more oxidized species.

Figure 4 shows the evolution of the O:C ratio for the different experiments. With an aging time of up to ten hours the produced SOA is relatively fresh compared to the possible lifetime in the ambient atmosphere. The overall range of 
$\mathrm{O}: \mathrm{C}$ ratios observed during all the experiments, $0.25-0.55$, is in the same range as the ambient SV-OOA (Jimenez et al., 2009). Upon nucleation, compounds with the lowest volatility are expected to form the first aerosol particles. As the mass concentration of OA increases the subsequent condensing SOA is slightly more volatile and, as suggested by Duplissy et al. (2008), therefore has a decreasing effect on the bulk $\mathrm{O}: \mathrm{C}$ ratio, which is indeed observed during the first hour of most experiments. During the following hours, the further increase in $\mathrm{OM}$ continues to change the equilibrium of the SVOCs and to drive more volatile compounds into the particle phase, counteracting the expected increase in the O:C ratio by aging and yielding a relatively constant $\mathrm{O}: \mathrm{C}$ ratio. After this period an increase in the O:C ratio is observed when the effect due to aging becomes more important than the one related to the addition of new mass. These effects are influenced by the concentration as well as the saturation vapor pressure distribution of the SVOCs.

Compared to the other sources, SOA from the scooter emissions showed the highest $\mathrm{O}: \mathrm{C}$ ratio in the initial phase of the experiment as well as during the full experiment duration, with an average value of 0.51 after five hours. The values for wood burning, diesel and $\alpha$-pinene were more similar with averaged ratios of $0.37,0.34$ and 0.39 , respectively. The high O:C ratio of the scooter SOA compared to the diesel SOA might be the result of smaller hydrocarbons comprising the gasoline fuel. Smaller hydrocarbons would need a higher degree of oxidation to reduce the saturation vapor pressure enough to partition to the aerosol phase. Although differences in $\mathrm{OH}$ exposure can be expected between the different experiments no major change in the order of $\mathrm{O}: \mathrm{C}$ ratio was observed for the different photo-oxidation experiments.

Factor analyses of ambient AMS spectra have typically described SOA in terms of oxygenated organic aerosol (OOA) factors. Two prominent peaks in the factor mass spectra of OOA, $m / z, 43$ and 44 , were used to show the dynamic evolution of $\mathrm{OOA}$ in the atmosphere during aging $(\mathrm{Ng}$ et al., 2010). The peak at $m / z 44$ is dominated by the $\mathrm{CO}_{2}^{+}$fragment formed by the thermal decarboxylation of carboxylic acids, with an increasing fraction $\mathrm{m} / \mathrm{z} 44$ ( $f 44)$ caused by an increasing number of carboxyl groups (Alfarra, 2004; Duplissy et al., 2011). Typically for OOA, the peak at $\mathrm{m} / \mathrm{z} 43$ has only a minor contribution of $\mathrm{C}_{3} \mathrm{H}_{7}^{+}$and is dominated by the oxygenated fragment $\mathrm{C}_{2} \mathrm{H}_{3} \mathrm{O}^{+}$which is expected to be mainly formed as a fragment of non-carboxylic oxygenated organic compounds (Ng et al., 2010). A triangular shape, shown in Fig. 5, was observed to accommodate ambient OOA when plotting the $f 44$ vs. $f 43$ space ( $\mathrm{Ng}$ et al., 2010). Relatively fresh, semivolatile OOA (SV-OOA) was found at the lower range of $f 44$ (up to $\sim 0.10$ ) whereas the more aged, lowvolatility OOA (LV-OOA) was found at higher $f 44$.

Besides this movement towards the upper left corner of the triangle during the aging process of OOA, the $f 44$ vs. $f 43$ space also shows some discrimination based on the source or precursor of the OOA. In chamber studies, SOA from $\alpha$ -

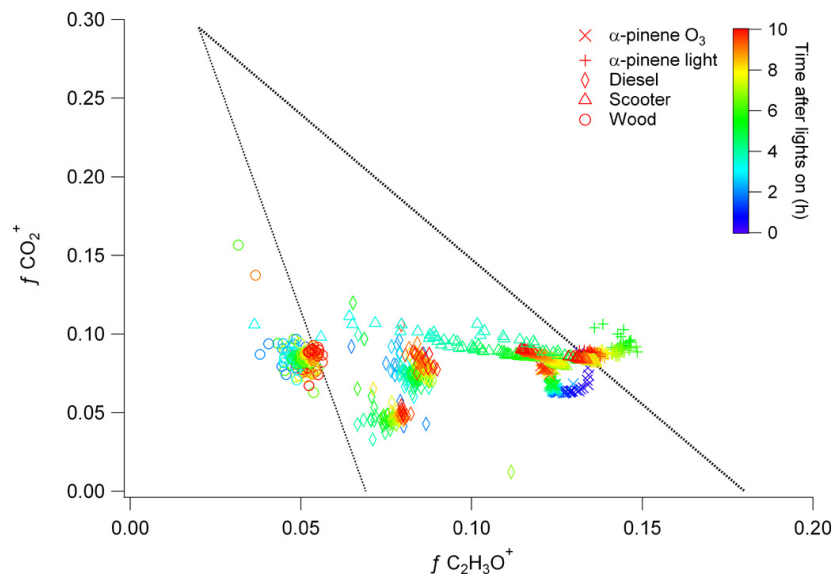

Fig. 5. Fraction of the high resolution fit $f \mathrm{CO}_{2}^{+}$vs. $f \mathrm{C}_{2} \mathrm{H}_{3} \mathrm{O}^{+}$ ( $f 44$ vs. $f 43$ ). The triangular space found by $\mathrm{Ng}$ et al. (2010) to accommodate the OOA component of ambient organic aerosol is shown as well.

pinene and isoprene was located at the right side of the triangle (Chhabra et al., 2011) while aged wood burning emissions were found at the edge of the left side of the triangle (Heringa et al., 2011). These findings are confirmed in Fig. 5. The SOA from the diesel car emissions as well as the SOA from the scooter exhaust gases show up in the middle region. All four types of experiments have a relatively constant $f 44$ during the five or ten hours of aging with $f 44$ ranging from $\sim 0.04$ to $\sim 0.10$ making it similar to SV-OOA.

In contrast to the similarity in $f 44$, a large range in $f 43$ was observed for the different types of SOA. In addition, $f 43$ was highly variable during the aging process indicating changes in the composition of the non-carboxylic oxygenated organic compounds. Although the different types of SOA showed a large range of $f 43$, the dynamic behavior of this fragment during aging makes it not ideal to estimate the contributions of the different SOA types to ambient OOA.

\subsection{Simplified approach for SOA separation}

Because of their similar AMS mass spectral properties, SOA from different biogenic and anthropogenic sources are usually grouped together and reported as OOA. In some data sets a relatively fresh SV-OOA and a highly aged LV-OOA could be distinguished. However, the contribution of specific sources to these OOA classes is often unknown. The AMS spectra of different types of SOA become more similar during aging and lose their original fingerprint when reaching the highly oxidized state (Jimenez et al., 2009) making it impossible to identify the contributions from the different sources. However, as shown in Figs. 3 and 5, the relatively fresh SV-OOA still contains differences that may be used for the differentiation of the different types of fresh SOA. 


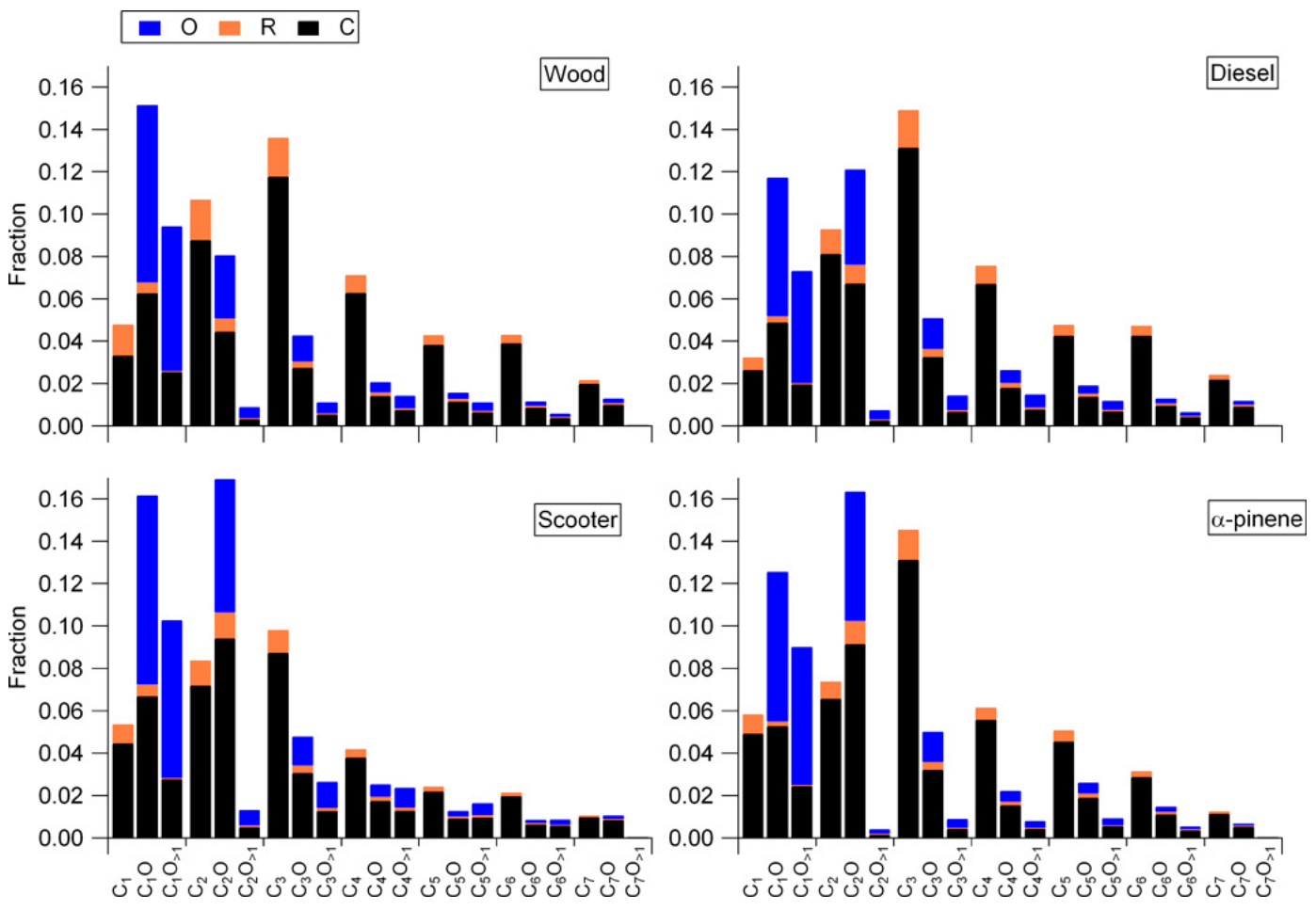

Fig. 6. Averaged normalized bar graphs for the different sources after five hours of aging. The bars represent the ion groups $C_{X}, C_{X} O_{1}$ and $\mathrm{C}_{\mathrm{x}} \mathrm{O}_{>1}$ for the number of carbon atoms, $x$, in the range of 1 to 7 . The individual bars are split in the contribution of carbon (black), oxygen (blue) and all other atoms, e.g. H or $\mathrm{N}$ (orange).

\subsubsection{Grouping of ions}

With the large number of ions present, the HR spectra not only contain more information than the UMR spectra, but are also more difficult to interpret. To simplify the HR mass spectrum, ions were grouped based on the number of carbon atoms of the fragment ion $\left(\mathrm{C}_{1}-\mathrm{C}_{7}\right)$ and its oxygenation state $\left(\mathrm{C}_{\mathrm{x}}, \mathrm{C}_{\mathrm{x}} \mathrm{O}_{1}, \mathrm{C}_{\mathrm{x}} \mathrm{O}_{>1}\right)$ resulting in 21 groups. An advantage of grouping ions is the fact that the random noise will be lower due to the averaging effect of several ions and that spectra with non-identical lists of fitted ions can easily be compared. On the other hand, single ions with a very unique signature will be "diluted" by other ions within the same group resulting in a trade-off between the number of variables and the level of information. The grouped spectra for the four SOA sources after five hours of aging are shown in Fig. 6.

Since the ions were grouped according to their number of carbons, the bar graphs show a carbon number based fragmentation distribution for the groups $\mathrm{C}_{\mathrm{x}}, \mathrm{C}_{\mathrm{x}} \mathrm{O}_{1}$ and $\mathrm{C}_{\mathrm{x}} \mathrm{O}_{>1}$. All four SOA sources show a maximum for the $\mathrm{C}_{\mathrm{x}}$ group for fragment ions with three carbons. In general, the $C_{x}$ group distributions for diesel, wood and $\alpha$-pinene are similar with $58 \%, 62 \%$ and $64 \%$ of the $\mathrm{C}_{\mathrm{x}}$ groups at $x \leq 3$, respectively. Scooter SOA, with $70 \%$ of the $\mathrm{C}_{\mathrm{x}}$ group at $x \leq 3$, had the largest fraction of small fragments. The same trend is seen for the accumulated signal of all three groups $\left(\mathrm{C}_{\mathrm{x}}, \mathrm{C}_{\mathrm{x}} \mathrm{O}_{1}\right.$ and
$\mathrm{C}_{\mathrm{x}} \mathrm{O}_{>1}$ ) up to three carbon atoms with $66 \%$ for the diesel SOA and $68 \%, 72 \%$ and $76 \%$ for the SOA from wood, $\alpha$ pinene and the scooter, respectively. The observation that the scooter SOA had the highest O:C ratio and the largest fraction of small ions could be explained by the higher degree of oxygenation needed for smaller molecules to reduce their vapor pressure enough to partition to the particle phase, as explained above. This is consistent with the relatively long period between lights on and nucleation observed for the scooter and $\alpha$-pinene photo-oxidation experiments. However, neither more severe fragmentation of more oxygenated molecules nor variations in $\mathrm{OH}$ concentrations for the different experiments can be excluded as possible causes.

Based on the calculated ion groups, the four SOA types were projected in a two-dimensional space. With the ratio of $\mathrm{C}_{2} / \mathrm{C}_{2} \mathrm{O}_{1}$ vs. $\mathrm{C}_{3} \mathrm{O}_{1} / \mathrm{C}_{3} \mathrm{O}_{>1}$ the four different types of SOA could be separated. Figure 7 shows the one-hourly averages of all eight experiments. The variation between the duplicate experiments is the largest for the $\mathrm{C}_{3} \mathrm{O}_{1} / \mathrm{C}_{3} \mathrm{O}_{>1}$ ratio. This variation could not be attributed to differences in concentration as it acts in opposite directions for the different experiment types. In addition, the duplicate experiments on the scooter emissions, which have the largest concentration variation, show the best clustering. Therefore the variation is assumed to be the result of the variation in the composition of the emissions and the aging conditions. The different 


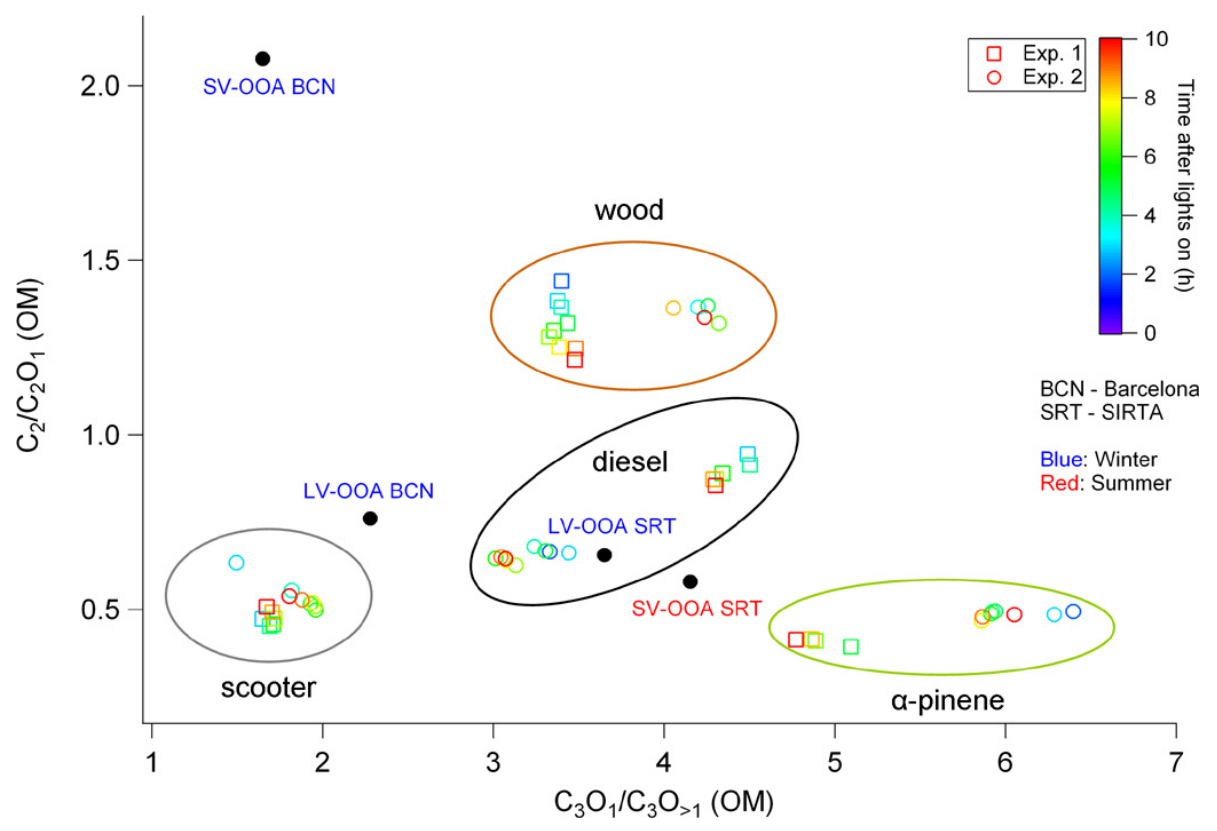

Fig. 7. SOA separation based on grouped ions. The symbols represent hourly averages of experiment 1 (squares) and 2 (circles) and are colored according to the aging time. Colored ovals are added to guide the eye and group the duplicate experiments. PMF resolved OOA spectra measured in SIRTA (Paris) and Barcelona are colored according to the season.

sources could be separated without overlap but the duplicate experiments do not cluster very well together showing that the model is lacking robustness. This is also seen when PMFresolved ambient SV-OOA spectra from Barcelona (Mohr et al., 2012) and the Paris SIRTA site (Crippa et al., 2012) are projected. A short description of these measurement sites is given in Sect. 3.4.2. The Barcelona SV-OOA spectrum, expected to have significant contribution of SOA from diesel emissions (see Sect. 3.4.2) does not cluster close to the diesel car SOA or any of the other SOA types. The SV-OOA from the SIRTA site (see also Sect. 3.4.2) falls in between the diesel car SOA and the $\alpha$-pinene SOA clusters. With an HOA contribution of $\sim 16 \%$ to $\mathrm{OM}$ a contribution of diesel car SOA is expected, but not as a dominant source. The produced smog chamber SOAs are relatively fresh and therefore can only be compared to SV-OOA. The LV-OOA spectra were added to show where they fall on the graph compared to the SV-OOA spectra, but are not further taken into account.

Although the diesel SOA cluster in Fig. 7 falls in between the cluster found for wood burning SOA and $\alpha$-pinene SOA, it cannot be concluded that the MS of a mixture of these SOA types is similar to diesel SOA. Spectral features not used for the separation shown in Fig. 7, like the typically low signal of the $\mathrm{C}_{1}$ group in the diesel SOA, could be used in addition to this data space projection. However, this suggests that AMS SOA spectra from different sources cannot easily be distinguished using only a few ions. A more comprehensive approach is therefore applied in the sections below.

\subsection{SOA separation by principal component analysis}

Principal component analysis was applied on the AMS spectra to improve the separation of the four different types of SOA produced in the smog chamber. This approach could also be applied to data from other instruments or data from a set of instruments. In addition, PCA can be used to reduce the dimension of the data set to a limited number of latent variables, called principal components (PCs). The different approaches that were tested are described in the following section.

\subsubsection{Building the PCA model}

As a first exploratory study, four different models were created. The first model was based on the averaged UMR spectra of the duplicate experiments recorded after five hours of aging. The spectrum of each experiment was averaged after five hours using an average time period of $16 \mathrm{~min}$. The second model was based on all the HR spectra from one experiment per SOA type whereas the third model contained all the HR spectra of all eight experiments. The last model was built with the averaged HR spectra of both duplicate experiments recorded after five hours of aging. The averaged UMR spectra were prepared by averaging the normalized organic using the $\mathrm{m} / \mathrm{z}$ range $12-250$. Because the PCA model attempts to explain the total variance, the time-resolved spectra of the experiments for model 2 and 3 were normalized as well to exclude the influence of varying concentrations. The averaged HR spectra were prepared by averaging the normalized 

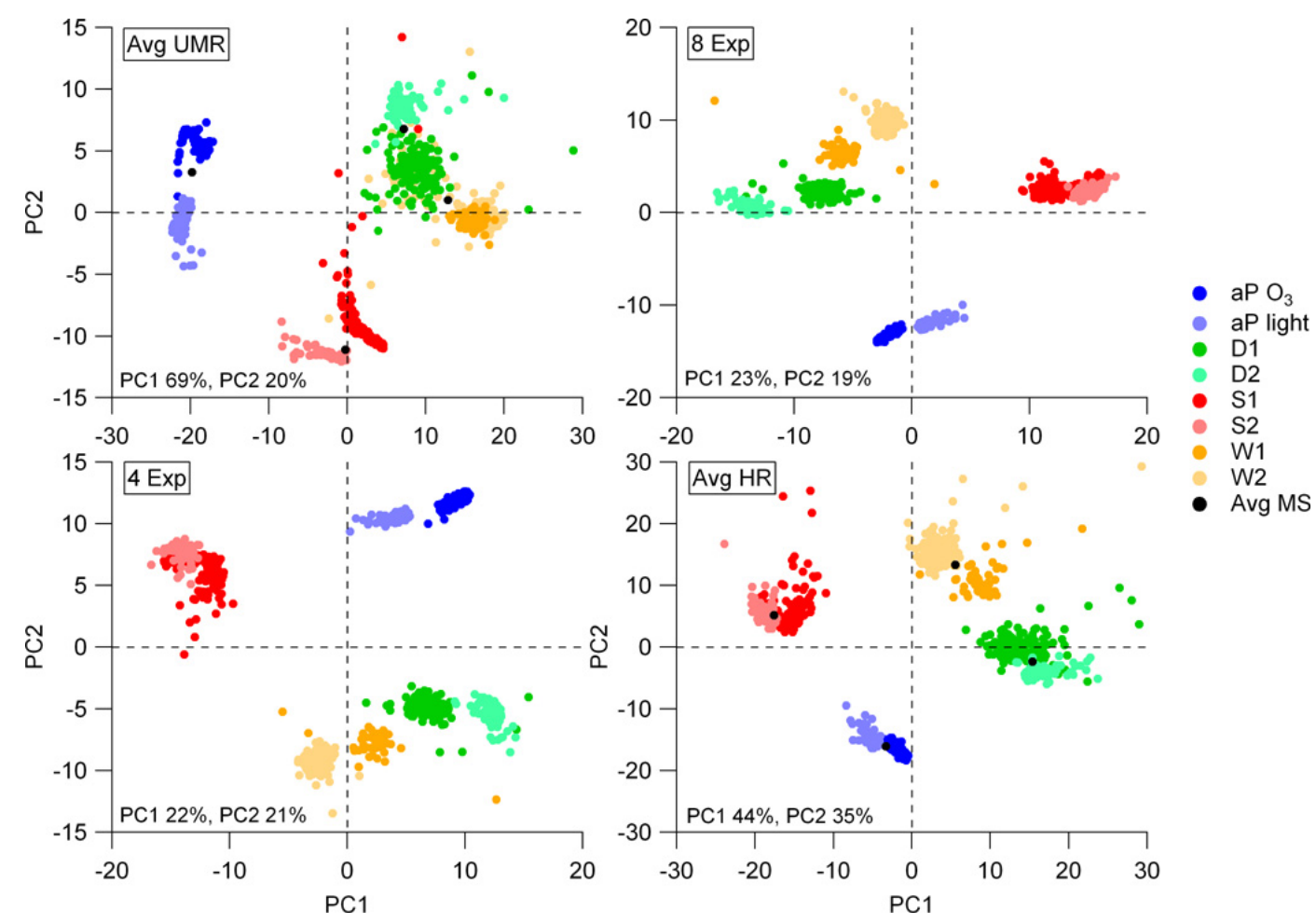

Fig. 8. Score plots of the four PCA models based on the average unit mass resolution spectra (Avg UMR), four high resolution experiments (4 Exp), all eight high resolution experiments ( $8 \mathrm{Exp}$ ) and the average high resolution spectra (Avg HR). The colored circles represent the data point from the $\alpha$-pinene (aP), diesel car (D), scooter (S) and wood burning (W) experiments. The black dots represent the averaged mass spectra. The percentage of variance explained by PC1 and PC2 are shown in the graphs.

organic HR spectrum of the duplicate experiments after five hours of aging using the ions fit in the $\mathrm{m} / \mathrm{z}$ range $12-120$. Ions that were not fit during the HR data analysis of all experiments were added to align the HR spectra of all eight experiments. The signal of these ions was set to zero based on the assumption that the ion was not fit because it was below detection limit in the HR spectrum. A score plot of the two first principal components (PC1 vs. PC2) of these four models is shown in Fig. 8.

$\mathrm{PC} 1_{\mathrm{UMR}}$ and $\mathrm{PC} 2_{\mathrm{UMR}}$ explained $89 \%$ of the variance between the four averaged UMR spectra. Projecting the experimental data in the model showed that the duplicate experiments were clustered together and that the $\alpha$-pinene and scooter SOA were well separated from the diesel and wood burning SOA which showed significant overlap such that an additional PC is required for the latter two. The first two PCs of the model based on the HR experimental data of four experiments explained $43 \%$ of the variance. The model showed good separation of the four different sources and fair clustering of the duplicate experiments projected in the model. The model based on all eight experiments yielded similar results as the previous model and explained $42 \%$ of the variation with the first two PCs. The scooter experiments are well separated from the three other experiments by $\mathrm{PC}_{8 \mathrm{exp}}$, and in the same way, $\alpha$-pinene experiments are well separated by PC2 8 exp. Like the UMR model, a third $\mathrm{PC}$ is necessary to achieve the separation between the diesel SOA and the wood burning SOA. The averaged HR spectra model showed a significant separation of the four SOA types and a decent clustering of the duplicate experiments on the first two $\mathrm{PCs}, \mathrm{PC} 1_{\mathrm{HR}}$ and $\mathrm{PC} 2_{\mathrm{HR}}$, which explained $79 \%$ of the total variance.

Although the first two PCs of the model based on the averaged HR spectra explain a lower fraction of variance than the model based on the averaged UMR spectra, it provides better clustering (therefore robustness), making it more suitable for predictive purposes. This is likely because the additional information included in the HR spectra compared to the UMR spectra enhances the discrimination between the SOA types, even though a larger fraction of the total variance is not explained. Therefore, from here on the results will be presented in the model built on the averaged HR mass spectra. The loading plot (Figs. 9 and SI-1), shows that only a small number of ions are found in the center region of the plot, i.e. have a weak contribution to the first two PCs. This implies that almost all ions contribute similarly to the separation of the first two PCs and that HR spectra that were fit using a smaller $\mathrm{m} / \mathrm{z}$ range than the 12-120 used for the model cannot be displayed with this model due to the large number of missing ions relevant for the model. The PCA procedure can also 

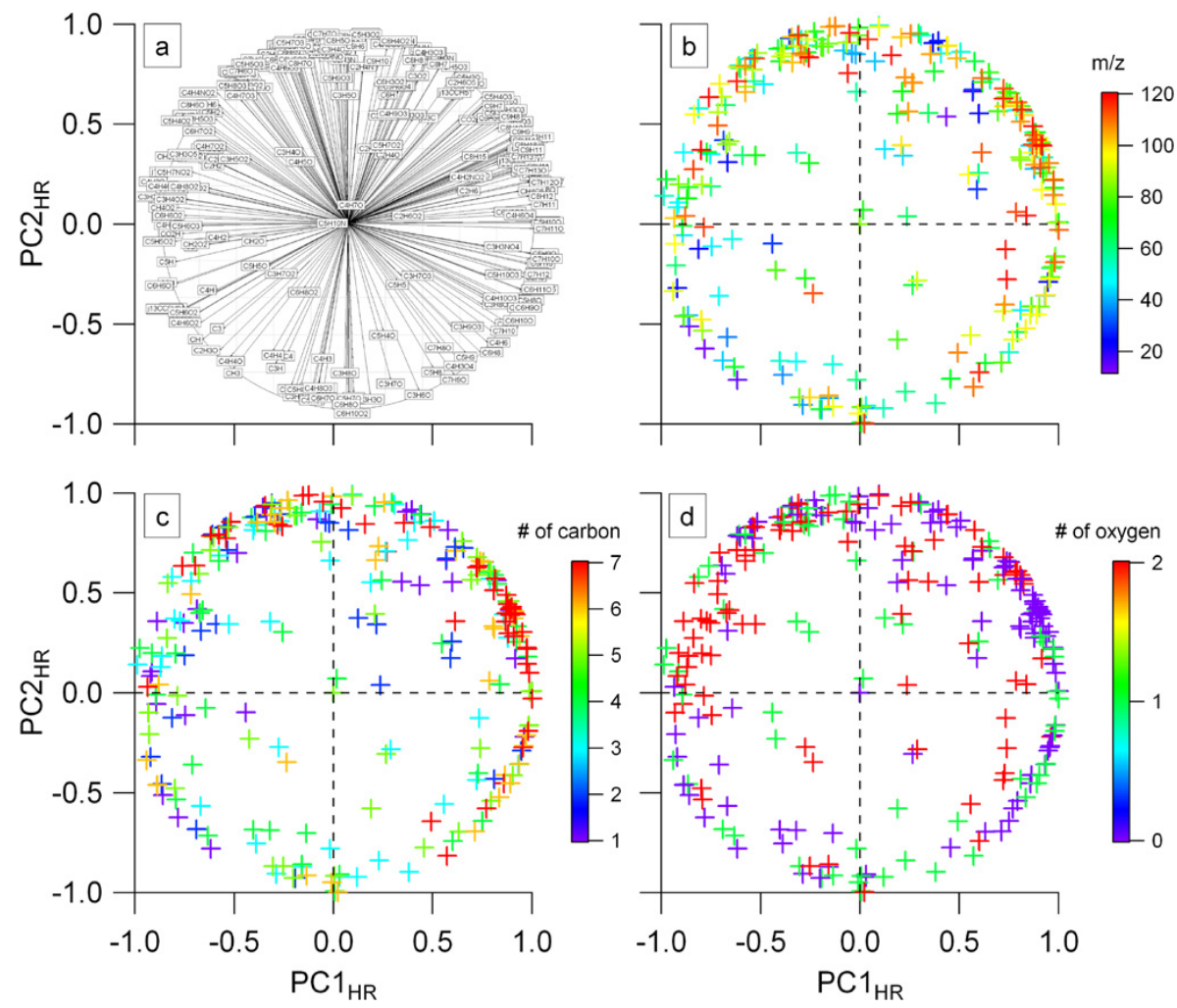

Fig. 9. Loading plots (PC2 vs. PC1) of the HR PCA model. The first panel shows the 337 ions that were fit in the $m / z$ range $12-120$ (see the supplementary information for a larger version). Panel b, $\mathrm{c}$ and $\mathrm{d}$ show the loading plot colored by the mass of the ions, the number of carbon atoms and the number of oxygen atoms respectively.

separate SOA mass spectra using a reduced $\mathrm{m} / \mathrm{z}$ range (e.g. 12-100), but better separation was achieved with a larger range.

The loading plot colored by the $m / z$ 's of the ions (Fig. 9b) indicates that the largest fragments have a positive contribution to $\mathrm{PC}_{\mathrm{HR}}$ where the smaller fragments have a negative contribution. Scooter SOA, the source with the largest fraction of small ions in the grouped mass spectra (Sect. 3.3.1) had the lowest score on $\mathrm{PC}_{\mathrm{HR}}$. This agreement was also found for the other three sources with the diesel SOA having the largest score on $\mathrm{PC} 1_{\mathrm{HR}}$. Figure $9 \mathrm{c}, \mathrm{d}$ reveals that the ions with high carbon numbers have in general a positive contribution to $\mathrm{PC} 1_{\mathrm{HR}}$ where the ions with two oxygen atoms have a negative contribution to $\mathrm{PC}_{\mathrm{HR}}$. This is in agreement with the high O:C ratio of the scooter SOA having the lowest score on $\mathrm{PC}_{\mathrm{HR}}$ and the lower $\mathrm{O}: \mathrm{C}$ ratio of the diesel SOA having the largest scores on $\mathrm{PC}_{\mathrm{HR}}$.

Although there are general trends observed in Fig. 9, ions that are similar in $\mathrm{m} / \mathrm{z}$, number of carbon or number of oxygen atoms, can have opposite contributions to the PCs. This effect is likely to reduce the resolving power of models using ions that are grouped based on their similarity in these properties. An Excel file with the parameters of the HR model can be found in the supplementary information and used to calculate the coordinates of a spectrum in the modeled space.

\subsubsection{Projection of ambient OOA spectra}

The PCA model based on the averaged HR spectra was used to project OOA spectra that were extracted by PMF from ambient datasets. Figure 10 shows the four averaged HR spectra, the eight projected chamber experiments and the set of OOA spectra from the ambient data. Summer (2009) and winter (2010) data were taken at "Site Instrumental de Recherche par Télédétection Atmosphérique" (SIRTA) as part of the "MEGAPOLI" project. The measurement site was located in a semi-urban environment $20 \mathrm{~km}$ south of Paris, France. A detailed description of the measurement site, sampling setup and the data analysis can be found elsewhere (Crippa et al., 2012). The third data set, acquired during the winter 2009 "DAURE" campaign in Barcelona, Spain, is from a measurement station located in the northwestern corner of the city centre at a distance of $\sim 300 \mathrm{~m}$ from one of the main traffic arteries crossing the city (Mohr et al., 2012; Pandolfi et al., 2012).

Total OOA (SV-OOA + LV-OOA) in Barcelona was found to have a fossil carbon fraction of $40 \%$ (Minguillón et al., 2011; Mohr et al., 2012). Based on the large number of diesel cars (>45\% (Reche et al., 2011)) a significant contribution of SOA from diesel car emissions to OOA can indeed be expected. The projection of the Barcelona SV-OOA 


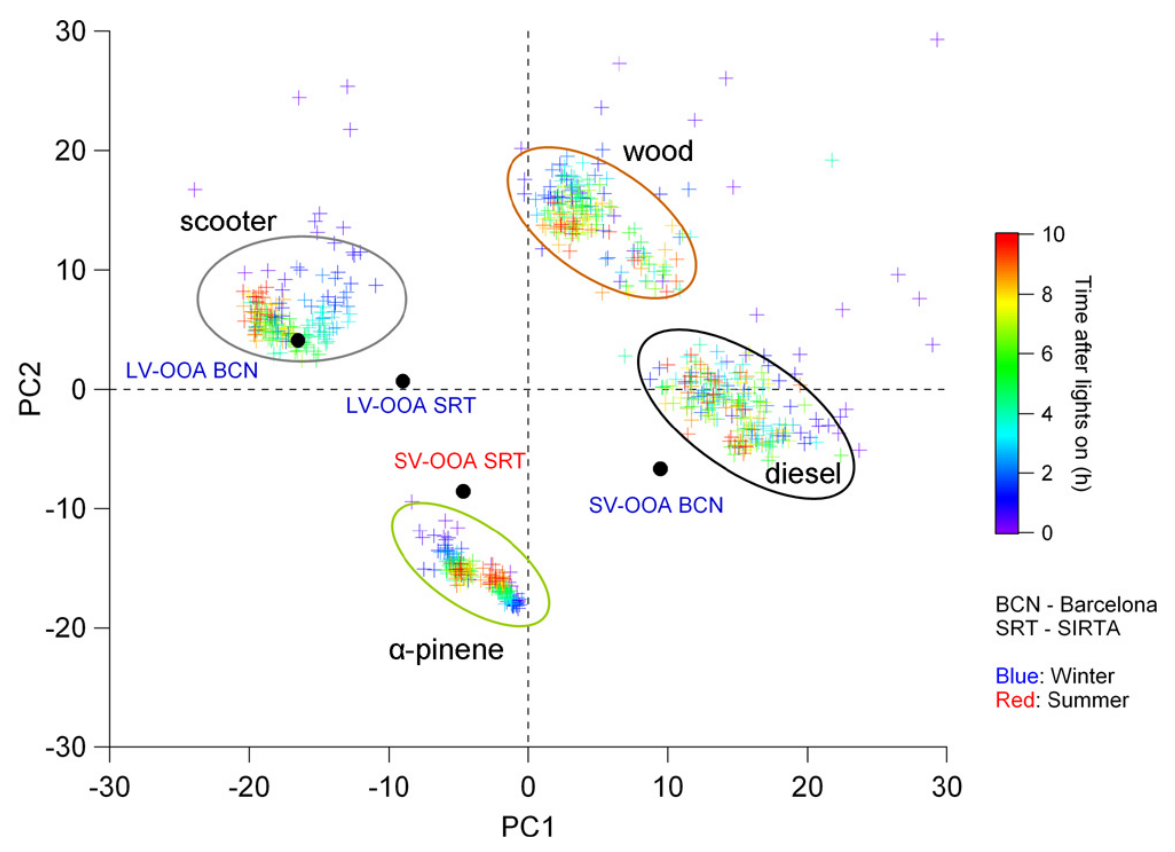

Fig. 10. PCA model based on the HR source spectra after five hours of aging. The data points of all eight experiments are projected and colored according to the aging time. The ovals are added to guide the eye and define where $\sim 95 \%$ of the data points fall. PMF resolved OOA spectra from different field campaigns are marked in red and blue text indicating summer and winter, respectively.

spectrum in Fig. 10 showed that it is positioned in between the $\alpha$-pinene and diesel SOA but closer to the diesel cluster. The projected SV-OOA spectrum recorded in summer at the SIRTA site shows high similarity with $\alpha$-pinene. Based on the $16 \%$ HOA contribution to OM a larger influence of diesel SOA was expected for this site. However, a SOA source not present in the model, e.g. cooking or gasoline cars, could in general cause interferences and change the position of the spectrum in the graph.

The projection of the PMF retrieved POA spectra found at the SIRTA site and in Barcelona is shown in Fig. SI-2. Although the PCA model was not built for primary spectra, it shows that the cooking OA (COA) factor found in Barcelona and SIRTA cluster well on the graph. HOA spectra are found close to the diesel SOA cluster with the Barcelona HOA factor at the edge of the plot close to the first data points after nucleation. The two primary biomass burning factors (BBOA) do not show high similarity in the PCA model and appear at different positions.

\section{Conclusions}

A series of smog chamber experiments were performed to investigate the SOA characteristics produced from the emissions of three different anthropogenic sources. The mass spectral features of a log wood burner, a Euro 2 diesel car and a Euro 2 scooter were acquired by an Aerodyne HRTOF-AMS and compared to SOA from $\alpha$-pinene.
The averaged UMR mass spectra of the duplicate experiments in the $m / z$ range $12-250$ showed Pearson's $r$ values $>0.94$ for the correlations between all four SOA types after five hours of aging. HR mass spectra showed that the dominant peaks at $m / z, 43$ and 44 are dominated by the oxygenated ions $\mathrm{C}_{2} \mathrm{H}_{3} \mathrm{O}^{+}$and $\mathrm{CO}_{2}^{+}$, respectively, also observed for the relatively fresh SV-OOA in the ambient aerosol ( $\mathrm{Ng}$ et al., 2010). The atomic O:C ratios were found in the range of $0.25-0.55$ with no major increase during the first five hours of aging, which is likely due to the fact that the expected increase by aging is compensated by the change in gas-toparticle partitioning by the increase in the $\mathrm{OM}$ concentration. On average, the diesel SOA showed the lowest O:C ratio followed by the SOA from wood burning, $\alpha$-pinene and scooter. Grouping the fragment ions based on their carbon number revealed that the SOA source with the highest O:C ratio had the largest fraction of small ions. Fragment ions containing up to three carbon atoms accounted for $66 \%, 68 \%, 72 \%$ and $76 \%$ of the organic spectrum of the SOA produced by the diesel car, wood burner, $\alpha$-pinene and the scooter, respectively. This observation could be explained by the higher degree of oxygenation needed for smaller molecules to reduce their vapor pressure enough to partition to the particle phase. However, a higher degree of fragmentation for more oxygenated molecules cannot be excluded.

Principal component analysis showed that it is possible to separate the four types of relatively fresh SOA produced by photo-oxidation/ozonolysis in a smog chamber. Using this first exploratory analysis, ambient SV-OOA spectra retrieved 
by PMF can be projected and, if dominated by one of the modeled sources, give information about source type. A more sophisticated multivariate analysis using a larger set of SOA sources could lead toward classification methods for prediction purposes. However, this can only be achieved when PMF is able to assign all the SOA source specific features to the SV-OOA factor. As an alternative approach, these HR SOA spectra from different sources might be used to constrain expected SOA factors in ambient data using the multilinear engine (ME-2) as was shown to be successful for primary sources (Lanz et al., 2008).

\section{Supplementary material related to this article is available online at: http://www.atmos-chem-phys.net/12/2189/2012/ acp-12-2189-2012-supplement.zip.}

Acknowledgements. This work was supported by the IMBALANCE project of the Competence Center Environment and Sustainability of the ETH Domain (CCES), by the NEADS project of the Competence Center Energy and Mobility (CCEM), the Bundesamt für Umwelt (BAFU), the Bundesamt für Energie (BFE), as well as the Swiss National Science Foundation. We thank René Richter and Günther Wehrle for their technical support at the smog chamber and Stephen Platt for his support during the scooter experiments. PFD is grateful for the postdoctoral support from the US-NSF (IRFP\# 0701013). Attika Feuer AG is kindly acknowledged for the provided wood stove.

Edited by: V.-M. Kerminen

\section{References}

Aiken, A. C., DeCarlo, P. F., and Jimenez, J. L.: Elemental analysis of organic species with electron ionization highresolution mass spectrometry, Anal. Chem., 79, 8350-8358, doi:10.1021/ac071150w, 2007.

Aiken, A. C., DeCarlo, P. F., Kroll, J. H., Worsnop, D. R., Huffman, J. A., Docherty, K. S., Ulbrich, I. M., Mohr, C., Kimmel, J. R., Sueper, D., Sun, Y., Zhang, Q., Trimborn, A., Northway, M., Ziemann, P. J., Canagaratna, M. R., Onasch, T. B., Alfarra, M. R., Prevot, A. S. H., Dommen, J., Duplissy, J., Metzger, A., Baltensperger, U., and Jimenez, J. L.: O/C and OM/OC ratios of primary, secondary, and ambient organic aerosols with high-resolution time-of-flight aerosol mass spectrometry, Environ. Sci. Technol., 42, 4478-4485, 2008.

Alfarra, M. R.: Insights into the atmospheric organic aerosols using an aerosol mass spectrometer, Thesis, Institute of Science and Technology, University of Manchester, UK, 2004.

Allan, J. D., Delia, A. E., Coe, H., Bower, K. N., Alfarra, M. R., Jimenez, J. L., Middlebrook, A. M., Drewnick, F., Onasch, T. B., Canagaratna, M. R., Jayne, J. T., and Worsnop, D. R.: A generalised method for the extraction of chemically resolved mass spectra from Aerodyne aerosol mass spectrometer data, J. Aerosol Sci., 35, 909-922, 2004.

Allan, J. D., Williams, P. I., Morgan, W. T., Martin, C. L., Flynn, M. J., Lee, J., Nemitz, E., Phillips, G. J., Gallagher, M. W., and
Coe, H.: Contributions from transport, solid fuel burning and cooking to primary organic aerosols in two UK cities, Atmos. Chem. Phys., 10, 647-668, doi:10.5194/acp-10-647-2010, 2010. Andreani-Aksoyoglu, S., Keller, J., Prevot, A. S. H., Baltensperger, U., and Flemming, J.: Secondary aerosols in Switzerland and northern Italy: Modeling and sensitivity studies for summer 2003, J. Geophys. Res., 113, D06303, doi:10.1029/2007JD009053, 2008.

Capes, G., Johnson, B., McFiggans, G., Williams, P. I., Haywood, J., and Coe, H.: Aging of biomass burning aerosols over West Africa: Aircraft measurements of chemical composition, microphysical properties, and emission ratios, J. Geophys. Res., 113, D00C15, doi:10.1029/2008JD009845, 2008.

Chhabra, P. S., Ng, N. L., Canagaratna, M. R., Corrigan, A. L., Russell, L. M., Worsnop, D. R., Flagan, R. C., and Seinfeld, J. H.: Elemental composition and oxidation of chamber organic aerosol, Atmos. Chem. Phys., 11, 8827-8845, doi:10.5194/acp-11-88272011, 2011.

Chirico, R., DeCarlo, P. F., Heringa, M. F., Tritscher, T., Richter, R., Prévôt, A. S. H., Dommen, J., Weingartner, E., Wehrle, G., Gysel, M., Laborde, M., and Baltensperger, U.: Impact of aftertreatment devices on primary emissions and secondary organic aerosol formation potential from in-use diesel vehicles: results from smog chamber experiments, Atmos. Chem. Phys., 10, 11545-11563, doi:10.5194/acp-10-11545-2010, 2010.

Crippa, M., DeCarlo, P. F., Mohr, C., Heringa, M. F., Chirico, R., Slowik, J. G., Poulain, L., Wiedensohler, A., Freutel, F., Drewnick, F., Schneider, J., Di Marco, C. F., Eiko, N., Zimmermann, R., Elsasser, M., Sciare, J., Prevot, A. S. H., and Baltensperger, U.: Wintertime aerosol chemical composition and source apportionment of the organic fraction in the metropolitan area of Paris, in preparation, 2012.

DeCarlo, P. F., Kimmel, J. R., Trimborn, A., Northway, M. J., Jayne, J. T., Aiken, A. C., Gonin, M., Fuhrer, K., Horvath, T., Docherty, K. S., Worsnop, D. R., and Jimenez, J. L.: Field-deployable, high-resolution, time-of-flight aerosol mass spectrometer, Anal. Chem., 78, 8281-8289, doi:10.1021/ac061249n, 2006.

DeCarlo, P. F., Ulbrich, I. M., Crounse, J., de Foy, B., Dunlea, E. J., Aiken, A. C., Knapp, D., Weinheimer, A. J., Campos, T., Wennberg, P. O., and Jimenez, J. L.: Investigation of the sources and processing of organic aerosol over the Central Mexican Plateau from aircraft measurements during MILAGRO, Atmos. Chem. Phys., 10, 5257-5280, doi:10.5194/acp-10-52572010, 2010.

Donahue, N. M., Robinson, A. L., Stanier, C. O., and Pandis, S. N.: Coupled partitioning, dilution, and chemical aging of semivolatile organics, Environ. Sci. Technol., 40, 2635-2643, 2006.

Dray, S. and Dufour, A. B.: The ade4 package: Implementing the duality diagram for ecologists, J. Stat. Softw., 22, 1-20, 2007.

Duplissy, J., Gysel, M., Alfarra, M. R., Dommen, J., Metzger, A., Prevot, A. S. H., Weingartner, E., Laaksonen, A., Raatikainen, T., Good, N., Turner, S. F., McFiggans, G., and Baltensperger, U.: Cloud forming potential of secondary organic aerosol under near atmospheric conditions, Geophys. Res. Lett., 35, L03818, doi:10.1029/2007GL031075, 2008.

Duplissy, J., DeCarlo, P. F., Dommen, J., Alfarra, M. R., Metzger, A., Barmpadimos, I., Prevot, A. S. H., Weingartner, E., Tritscher, T., Gysel, M., Aiken, A. C., Jimenez, J. L., Cana- 
garatna, M. R., Worsnop, D. R., Collins, D. R., Tomlinson, J., and Baltensperger, U.: Relating hygroscopicity and composition of organic aerosol particulate matter, Atmos. Chem. Phys., 11, 1155-1165, doi:10.5194/acp-11-1155-2011, 2011.

Farina, S. C., Adams, P. J., and Pandis, S. N.: Modeling global secondary organic aerosol formation and processing with the volatility basis set: Implications for anthropogenic secondary organic aerosol, J. Geophys. Res., 115, D09202, doi:10.1029/2009JD013046, 2010.

Grieshop, A. P., Logue, J. M., Donahue, N. M., and Robinson, A. L.: Laboratory investigation of photochemical oxidation of organic aerosol from wood fires 1: measurement and simulation of organic aerosol evolution, Atmos. Chem. Phys., 9, 1263-1277, doi:10.5194/acp-9-1263-2009, 2009.

Hallquist, M., Wenger, J. C., Baltensperger, U., Rudich, Y., Simpson, D., Claeys, M., Dommen, J., Donahue, N. M., George, C., Goldstein, A. H., Hamilton, J. F., Herrmann, H., Hoffmann, T., Iinuma, Y., Jang, M., Jenkin, M. E., Jimenez, J. L., Kiendler-Scharr, A., Maenhaut, W., McFiggans, G., Mentel, Th. F., Monod, A., Prévôt, A. S. H., Seinfeld, J. H., Surratt, J. D., Szmigielski, R., and Wildt, J.: The formation, properties and impact of secondary organic aerosol: current and emerging issues, Atmos. Chem. Phys., 9, 5155-5236, doi:10.5194/acp-95155-2009, 2009.

Heringa, M. F., DeCarlo, P. F., Chirico, R., Tritscher, T., Dommen, J., Weingartner, E., Richter, R., Wehrle, G., Prévôt, A. S. H., and Baltensperger, U.: Investigations of primary and secondary particulate matter of different wood combustion appliances with a high-resolution time-of-flight aerosol mass spectrometer, Atmos. Chem. Phys., 11, 5945-5957, doi:10.5194/acp-11-59452011, 2011.

Huang, X.-F., He, L.-Y., Hu, M., Canagaratna, M. R., Sun, Y., Zhang, Q., Zhu, T., Xue, L., Zeng, L.-W., Liu, X.-G., Zhang, Y.-H., Jayne, J. T., Ng, N. L., and Worsnop, D. R.: Highly time-resolved chemical characterization of atmospheric submicron particles during 2008 Beijing Olympic Games using an Aerodyne High-Resolution Aerosol Mass Spectrometer, Atmos. Chem. Phys., 10, 8933-8945, doi:10.5194/acp-10-8933-2010, 2010.

IPCC: Fourth Assessment Report: The Physical Science Basis, Working Group I, Final Report, Geneva, Switzerland, available from: http://www.ipcc.ch/ipccreports/ar4-wg1.htm, 2007.

Jimenez, J. L., Canagaratna, M. R., Donahue, N. M., Prevot, A. S. H., Zhang, Q., Kroll, J. H., DeCarlo, P. F., Allan, J. D., Coe, H., Ng, N. L., Aiken, A. C., Docherty, K. S., Ulbrich, I. M., Grieshop, A. P., Robinson, A. L., Duplissy, J., Smith, J. D., Wilson, K. R., Lanz, V. A., Hueglin, C., Sun, Y. L., Tian, J., Laaksonen, A., Raatikainen, T., Rautiainen, J., Vaattovaara, P., Ehn, M., Kulmala, M., Tomlinson, J. M., Collins, D. R., Cubison, M. J., Dunlea, E. J., Huffman, J. A., Onasch, T. B., Alfarra, M. R., Williams, P. I., Bower, K., Kondo, Y., Schneider, J., Drewnick, F., Borrmann, S., Weimer, S., Demerjian, K., Salcedo, D., Cottrell, L., Griffin, R., Takami, A., Miyoshi, T., Hatakeyama, S., Shimono, A., Sun, J. Y., Zhang, Y. M., Dzepina, K., Kimmel, J. R., Sueper, D., Jayne, J. T., Herndon, S. C., Trimborn, A. M., Williams, L. R., Wood, E. C., Middlebrook, A. M., Kolb, C. E., Baltensperger, U., and Worsnop, D. R.: Evolution of organic aerosols in the atmosphere, Science, 326, 1525-1529, 2009.

Kleindienst, T. E., Jaoui, M., Lewandowski, M., Offenberg, J. H.,
Lewis, C. W., Bhave, P. V., and Edney, E. O.: Estimates of the contributions of biogenic and anthropogenic hydrocarbons to secondary organic aerosol at a southeastern US location, Atmos. Environ., 41, 8288-8300, 2007.

Lanz, V. A., Alfarra, M. R., Baltensperger, U., Buchmann, B., Hueglin, C., and Prévôt, A. S. H.: Source apportionment of submicron organic aerosols at an urban site by factor analytical modelling of aerosol mass spectra, Atmos. Chem. Phys., 7, 1503-1522, doi:10.5194/acp-7-1503-2007, 2007.

Lanz, V. A., Alfarra, M. R., Baltensperger, U., Buchmann, B., Hueglin, C., Szidat, S., Wehrli, M. N., Wacker, L., Weimer, S., Caseiro, A., Puxbaum, H., and Prevot, A. S. H.: Source attribution of submicron organic aerosols during wintertime inversions by advanced factor analysis of aerosol mass spectra, Environ. Sci. Technol., 42, 214-220, 2008.

Lanz, V. A., Prévôt, A. S. H., Alfarra, M. R., Weimer, S., Mohr, C., DeCarlo, P. F., Gianini, M. F. D., Hueglin, C., Schneider, J., Favez, O., D’Anna, B., George, C., and Baltensperger, U.: Characterization of aerosol chemical composition with aerosol mass spectrometry in Central Europe: an overview, Atmos. Chem. Phys., 10, 10453-10471, doi:10.5194/acp-10-10453-2010, 2010.

Lewandowski, M., Jaoui, M., Offenberg, J. H., Kleindienst, T. E., Edney, E. O., Sheesley, R. J., and Schauer, J. J.: Primary and secondary contributions to ambient PM in the Midwestern United States, Environ. Sci. Technol., 42, 3303-3309, 2008.

Minguillón, M. C., Perron, N., Querol, X., Szidat, S., Fahrni, S. M., Alastuey, A., Jimenez, J. L., Mohr, C., Ortega, A. M., Day, D. A., Lanz, V. A., Wacker, L., Reche, C., Cusack, M., Amato, F., Kiss, G., Hoffer, A., Decesari, S., Moretti, F., Hillamo, R., Teinilä, K., Seco, R., Peñuelas, J., Metzger, A., Schallhart, S., Müller, M., Hansel, A., Burkhart, J. F., Baltensperger, U., and Prévôt, A. S. H.: Fossil versus contemporary sources of fine elemental and organic carbonaceous particulate matter during the DAURE campaign in Northeast Spain, Atmos. Chem. Phys., 11, 1206712084, doi:10.5194/acp-11-12067-2011, 2011.

Mohr, C., DeCarlo, P. F., Heringa, M. F., Chirico, R., Slowik, J. G., Richter, R., Reche, C., Alastuey, A., Querol, X., Seco, R., Peuelas, J., Jiménez, J. L., Crippa, M., Zimmermann, R., Baltensperger, U., and Prévôt, A. S. H.: Identification and quantification of organic aerosol from cooking and other sources in Barcelona using aerosol mass spectrometer data, Atmos. Chem. Phys., 12, 1649-1665, doi:10.5194/acp-12-1649-2012, 2012.

Nel, A.: Air pollution-related illness: Effects of particles, Science, 308, 804-806, 2005.

Ng, N. L., Canagaratna, M. R., Zhang, Q., Jimenez, J. L., Tian, J., Ulbrich, I. M., Kroll, J. H., Docherty, K. S., Chhabra, P. S., Bahreini, R., Murphy, S. M., Seinfeld, J. H., Hildebrandt, L., Donahue, N. M., DeCarlo, P. F., Lanz, V. A., Prévôt, A. S. H., Dinar, E., Rudich, Y., and Worsnop, D. R.: Organic aerosol components observed in Northern Hemispheric datasets from Aerosol Mass Spectrometry, Atmos. Chem. Phys., 10, 46254641, doi:10.5194/acp-10-4625-2010, 2010.

Pandolfi, M., Querol, X., Alastuey, A., Jimenez, J. L., Cusack, M., Reche, C., Pey, J., Mohr, C., DeCarlo, P. F., Ortega, A., Day, D., Prevot, A. S. H., Baltensperger, U., Artiñano, B., Baldasano, J. M., Jorba, O., Burkhart, J., Hansel, A., Schallhart, S., Müller, M., Metzger, M., Saarikoski, S., Cubison, M. J., Ng, S., Lorente, J., Nemitz, E., Di Marco, C., Peñuelas, J., Sicard, M., Comern, A., Amato, F., Moreno, T., Viana, M., Pérez, N., Moreno, N., Seco, 
R., Filella, I., Llusià, J., Piot, M., and Pay, M. T.: Sources and origin of PM in the Western Mediterranean Basin: An overview of the DAURE campaign, in preparation, 2012.

Paulsen, D., Dommen, J., Kalberer, M., Prevot, A. S. H., Richter, R., Sax, M., Steinbacher, M., Weingartner, E., and Baltensperger, U.: Secondary organic aerosol formation by irradiation of 1,3,5trimethylbenzene- $\mathrm{NO}_{\mathrm{x}}-\mathrm{H}_{2} \mathrm{O}$ in a new reaction chamber for atmospheric chemistry and physics, Environ. Sci. Technol., 39, 2668-2678, 2005.

Platt, S. M., Chirico, R., Clairotte, M., Barmet, P., Pfaffenberger, L., Slowik, J. G., Heringa, M. F., Fuller, S. J., Kalberer, M., Astorga, C., Dommen, J., Baltensperger, U., and Prevot, A. S. H.: Primary and secondary organic aerosol emissions from 2-stroke mopeds, in preparation, 2012.

Pope, C. A. and Dockery, D. W.: Health effects of fine particulate air pollution: Lines that connect, J. Air Waste Manage., 56, 709742, 2006.

Reche, C., Viana, M., Moreno, T., Querol, X., Alastuey, A., Pey, J., Pandolfi, M., Prevot, A. S. H., Mohr, C., Richard, A., Artinano, B., Gomez-Moreno, F. J., and Cots, N.: Peculiarities in atmospheric particle number and size-resolved speciation in an urban area in the western Mediterranean: Results from the DAURE campaign, Atmos. Environ., 45, 5282-5293, 2011.

Robinson, A. L., Donahue, N. M., Shrivastava, M. K., Weitkamp, E. A., Sage, A. M., Grieshop, A. P., Lane, T. E., Pierce, J. R., and Pandis, S. N.: Rethinking organic aerosols: Semivolatile emissions and photochemical aging, Science, 315, 1259-1262, 2007.
Schwartz, R. E., Russell, L. M., Sjostedt, S. J., Vlasenko, A., Slowik, J. G., Abbatt, J. P. D., Macdonald, A. M., Li, S. M., Liggio, J., Toom-Sauntry, D., and Leaitch, W. R.: Biogenic oxidized organic functional groups in aerosol particles from a mountain forest site and their similarities to laboratory chamber products, Atmos. Chem. Phys., 10, 5075-5088, doi:10.5194/acp-10-50752010, 2010.

Sun, Y.-L., Zhang, Q., Schwab, J. J., Demerjian, K. L., Chen, W.N., Bae, M.-S., Hung, H.-M., Hogrefe, O., Frank, B., Rattigan, O. V., and Lin, Y.-C.: Characterization of the sources and processes of organic and inorganic aerosols in New York city with a high-resolution time-of-flight aerosol mass spectrometer, Atmos. Chem. Phys., 11, 1581-1602, doi:10.5194/acp-11-15812011, 2011.

Watson, J. G.: Visibility: Science and regulation, J. Air Waste Manage., 52, 628-713, 2002.

Zhang, Q., Jimenez, J. L., Canagaratna, M. R., Allan, J. D., Coe, H., Ulbrich, I., Alfarra, M. R., Takami, A., Middlebrook, A. M., Sun, Y. L., Dzepina, K., Dunlea, E., Docherty, K., DeCarlo, P. F., Salcedo, D., Onasch, T., Jayne, J. T., Miyoshi, T., Shimono, A., Hatakeyama, S., Takegawa, N., Kondo, Y., Schneider, J., Drewnick, F., Borrmann, S., Weimer, S., Demerjian, K., Williams, P., Bower, K., Bahreini, R., Cottrell, L., Griffin, R. J., Rautiainen, J., Sun, J. Y., Zhang, Y. M., and Worsnop, D. R.: Ubiquity and dominance of oxygenated species in organic aerosols in anthropogenically-influenced Northern Hemisphere midlatitudes, Geophys. Res. Lett., 34, L13801, doi:10.1029/2007GL029979, 2007. 